\title{
Potential Role of the Sigma-1 Receptor Chaperone in the Beneficial Effects of Donepezil in Dementia with Lewy Bodies
}

\author{
Kenji Hashimoto \\ Division of Clinical Neuroscience, Chiba University Center for Forensic Mental Health, Chiba, Japan
}

\section{TO THE EDITOR}

With great interest, I read the article by Mori et al. ${ }^{1)}$ about a randomized, placebo-controlled trial of the cholinesterase (ChE) inhibitor donepezil for dementia with Lewy bodies (DLB). The study randomly assigned 140 DLB patients to receive placebo or donepezil hydrochloride $(3,5$, or $10 \mathrm{mg}$, daily for 12 weeks). The effects on cognition were assessed using the Mini-Mental State Examination (MMSE) and several domain-specific neuropsychological tests. Changes in behavior were evaluated using the Neuropsychiatric Inventory, caregiver burden using the Zarit Caregiver Burden Interview, and global function using the Clinician's Interview-Based Impression of Change-plus Caregiver Input (CIBIC-plus). Donepezil at 5 or $10 \mathrm{mg}$ was significantly superior to placebo on both the MMSE and CIBIC-plus, and $3 \mathrm{mg}$ donepezil was significantly superior to placebo on the CIBICplus, but not on the MMSE. Furthermore, a beneficial effect of donepezil was evident in each symptom domain characteristic of delusion, hallucination, and cognitive fluctuation (in DLB). Moreover, patients who received donepezil showed improved global function, as measured by the CIBIC-plus. These results suggest that donepezil ( 5 and $10 \mathrm{mg}$ /day) produces significant cognitive, behavioral, and global improvements in DLB patients, and that at the highest dose, this drug reduces the caregiver burden. ${ }^{1)}$

Cholinergic loss in DLB might be associated with cognitive deficits and neuropsychiatric symptoms, ${ }^{2)}$ although the precise pathogenesis of DLB is unclear. In contrast, accumulating evidence suggests that the sigma-1 receptor chaperone plays an important role in the pathophysiology

Received: November 28, 2012 / Accepted: November 30, 2012 Address for correspondence: Kenii Hashimoto, PhD Division of Clinical Neuroscience, Chiba University Center for Forensic Mental Health, 1-8-1 Inohana, Chiba 260-8670, Japan Tel: +81-43-226-2517, Fax: +81-43-226-2561 E-mail: hashimoto@faculty.chiba-u.jp of neuropsychiatric disorders, and that sigma-1 receptor agonists are potential therapy for neuropsychiatric disorders. ${ }^{3-6)}$ In addition to ChE inhibition, donepezil binds to the sigma-1 receptor chaperone in the brain with high affinity. ${ }^{7)}$ Furthermore, we reported that donepezil potentiated nerve growth factor-induced neurite outgrowth in PC12 cells, and that its effect was antagonized by treatment with NE-100 (4-methoxy-3-(2-phenylethoxy)-N,Ndipropylbenzeneethanamine hydrochloride) a sigma-1 receptor antagonist. ${ }^{8)}$ Moreover, we found that phencyclidine-induced cognitive deficits in mice were improved by the subchronic administration of donepezil, but not the ChE inhibitor physostigmine, and that its effect was antagonized by the co-administration of NE-100. ${ }^{7)}$ These findings suggest that the agonistic activity of donepezil at the sigma-1 receptor chaperone plays a role in the mechanisms of this drug in animal models of cognitive deficits. A positron emission tomography study demonstrated that donepezil ( 5 or $10 \mathrm{mg}$ ) binds to the sigma- 1 receptor in the living human brain at therapeutic doses, implicating the sigma-1 receptor chaperone in the pharmacological mechanism of donepezil in the human brain. ${ }^{9}$

Given the crucial role of the sigma-1 receptor chaperone in the pathophysiology of neuropsychiatric disorders, the sigma-1 receptor chaperone is likely involved in the beneficial effects of donepezil in DLB.

\section{REFERENCES}

1. Mori E, Ikeda M, Kosaka K; Donepezil-DLB Study Investigators. Donepezil for dementia with Lewy bodies: a randomized, placebo-controlled trial. Ann Neurol 2012;72:41-52.

2. Ballard C, Piggott M, Johnson M, Cairns N, Perry R, McKeith I, et al. Delusions associated with elevated muscarinic binding in dementia with Lewy bodies. Ann Neurol 2000; 48:868-876

3. Hashimoto K. Sigma-1 receptors and selective serotonin reuptake inhibitors: clinical implications of their relationship. Cent Nerv Syst Agents Med Chem 2009;9:197-204.

4. Niitsu T, Iyo M, Hashimoto K. Sigma-1 receptor agonists as therapeutic drugs for cognitive impairment in neuropsy-

(c) This is an Open-Access article distributed under the terms of the Creative Commons Attribution Non-Commercial License (http://creativecommons.org/licenses/by-nc/3.0) which permits unrestricted non-commercial use, distribution, and reproduction in any medium, provided the original work is properly cited. 
chiatric diseases. Curr Pharm Des 2012;18:875-883.

5. Hashimoto K, Furuse T. Sigma-1 receptor agonist fluvoxamine for delirium in older adults. Int $J$ Geriatr Psychiatry 2012;27:981-983.

6. Hashimoto K. Sigma-1 receptor chaperone and brain-derived neurotrophic factor: Emerging links between cardiovascular disease and depression. Prog Neurobiol 2013;100:15-29.

7. Kunitachi S, Fujita Y, Ishima T, Kohno M, Horio M, Tanibuchi Y, et al. Phencyclidine-induced cognitive deficits in mice are ameliorated by subsequent subchronic administration of donepezil: role of sigma-1 receptors. Brain Res
2009;1279:189-196.

8. Ishima T, Nishimura T, Iyo M, Hashimoto K. Potentiation of nerve growth factor-induced neurite outgrowth in PC12 cells by donepezil: role of sigma-1 receptors and IP3 receptors. Prog Neuropsychopharmacol Biol Psychiatry 2008;32: 1656-1659.

9. Ishikawa M, Sakata M, Ishii K, Kimura Y, Oda K, Toyohara $\mathrm{J}$, et al. High occupancy of sigmal receptors in the human brain after single oral administration of donepezil: a positron emission tomography study using $\left.{ }^{11} C\right]$ SA4503. Int $J$ Neuropsychopharmacol 2009;12:1127-1131. 